\title{
Potentiation of amphetamine-induced hyperactivity in the adult mouse following neonatal thyroxine administration
}

\author{
MICHAEL J. FORSTER, Z. MICHAEL NAGY, and JAMES M. MURPHY \\ Bowling Green State University, Bowling Green, Ohio 43403
}

\begin{abstract}
In order to examine possible long-term effects of neonatal hyperthyroidism on catecholamine (CA) neural systems, mice receiving saline or thyroxine injections during the neonatal period were subsequently injected with d-amphetamine or saline immediately prior to testing for locomotor activity at 100 days of age. Thyroxine-treated males were more active than control males following amphetamine injections, but thyroxine-treated and control females did not differ in this regard. In general, the results suggest that neonatal hyperthyroidism may have long-lasting effects on CA function that, at least at the age tested, may be limited to the male mouse.
\end{abstract}

Excess thyroid hormone in the neonatal rat or mouse affects a variety of central nervous system (CNS) processes, yielding a brief preweaning period of accelerated development followed by long-term physical and behavioral impairment (Davenport \& Gonzalez, 1973; Murphy \& Nagy, 1976; Schapiro, 1971). While many of the biochemical, electrophysiological, and anatomical correlates of thyroxine-accelerated maturation have been demonstrated during early development (Geel \& Timiras, 1967; Salas, Diaz, \& Cintra, 1976; Schapiro, 1968; Schapiro, Vukovich,\& Globus, 1973), considerably less information has accumulated with respect to the postweaning period of behavioral deficits. Such deficiencies have been generally attributed to the premature termination of certain phases of CNS development as a result of thyroxine-accelerated maturation (Schapiro, 1968, 1971).

In the present investigation, the possible long-term effects of early thyroxine treatment on the catecholamine (CA) system were investigated. Catecholamine systems were studied because thyroxine-CA interactions have previously been reported in both the infant and adult rat. The hyperthyroid state in the adult yields increased CA activity and increased CA receptor sensitivity (Emlen, Segal, \& Mandell, 1972; Engstrom, Svensson, \& Waldeck, 1974; Ito, Valcana, \& Timiras, 1977), as well as increased behavioral response to and toxicity of the CA stimulant amphetamine (Askew, 1962; Coville \& Telford, 1970; Halpern, Drudi-Baracco, $\&$ Bessirard, 1964). Some of these effects have also been

This research was supported by a grant from the National Institute of Child Health and Human Development (HD-09145) to Z. Michael Nagy. J. M. Murphy is now at the Institute for Psychiatric Research, Indiana University Medical Center, Indianapolis, Indiana. Reprint requests should be sent to Z. Michael Nagy, Department of Psychology, Bowling Green State University, Bowling Green, Ohio 43403. reported after neonatal hyperthyroidism (Rastogi \& Singhal, 1976). If early thyroxine treatment produces long-term alterations in the functioning of the CA system, then it was expected that adult mice that had previously received perinatal thyroxine treatments would respond differently from controls to pharmacological challenge with the CA stimulant d-amphetamine.

\section{METHOD}

\section{Subjects}

The subjects were 88 Swiss-Webster albino mice (Mus musculus) born and reared in the Bowling Green State University Psychology Department mouse colony. Mice were housed in $30.4 \times 18 \times 12.8 \mathrm{~cm}$ polyethylene cages with wire-grid tops and wood chips on the cage floors. Mothers remained with the pups at all times except for testing sessions and other experimental procedures. Mothers were provided nesting material and had ad-lib food and water available. The colony room was on a normal 12-h light-dark cycle beginning at $0800 \mathrm{~h}$ and was maintained at $24^{\circ} \mathrm{C} \pm 1^{\circ} \mathrm{C}$

\section{Apparatus}

Activity was monitored in clear Plexiglas cages measuring $26.5 \times 7.7 \times 10.0 \mathrm{~cm}$, with grid floors made from $1-\mathrm{mm}$-diam stainless steel rods spaced $5.0 \mathrm{~mm}$ center to center and extending parallel to the width of the cage. Two photocells, each paired opposite to a red-filtered light source, were located $5.0 \mathrm{~cm}$ from each end of the cage. A recording circuit was programmed such that one activity count was registered each time a mouse crossed alternate photocell beams. Thus, a mouse had to traverse the full $16.5-\mathrm{cm}$ distance between the photocells for each count. Cages were individually enclosed in sound-attenuated chambers, each with a 6-W incandescent ceiling light and a ventilation fan, which provided a $75-$ to $80-\mathrm{dB}$ ambient noise level within the chamber.

\section{Procedure}

Litters were selected that had been born on the previous day and contained at least 10 pups. Four males and four females with nearly equal weights were selected as subjects, and the remaining pups were sacrificed in order to maintain constant litter size of eight pups. Within each litter, two pups of each 
sex received 1 -microgram/g body weight intraperitoneal (ip) injections of thyroxine (L-thyroxine, Sigma Chemical Company) in saline suspension at 1,2 , and 3 days of age. The remaining four pups received similar saline injections. Litters were weaned at 30 days of age and housed four per cage until 100 days of age. At 100 days of age, 11 subjects of each sex from each early treatment group were injected with either d-amphetamine $(4 \mathrm{mg} / \mathrm{kg}$, ip, d-amphetamine sulfate, Smith, Kline, and French) or saline and immediately tested for activity in a 1-h session. Activity was analyzed as a function of $15-\mathrm{min}$ intervals.

\section{RESULTS}

The mean numbers of cage crossings are shown in Figure 1 as a function of early hormone treatment, drug condition during activity test, sex, and 15-min intervals; the total crossings per session are shown as a function of early hormone treatment, test drug, and sex in the figure inset. These data were analyzed by means of a four-way analysis of variance with one repeated measure (15-min intervals). As suggested by examination of the figure, amphetamine-treated mice were more active than saline-treated mice $[F(1,80)=32.80, p<.0005]$, and cage crossings showed an overall decrease over the 15 -min intervals $[F(3,240)=19.38, p<.0005]$. However, it is also clear that the response to amphetamine varied as a function of both early hormone treatment and sex, as indicated by a significant Drug by Sex interaction $[F(1,80)=5.97, p<.025]$ and a Hormone by Drug by Sex interaction that approached statistical significance $[F(3,240)=2.15, p<.10]$.

Planned comparisons among groups (after Winer, 1971), conducted within the Hormone by Drug by Sex interaction (shown in figure inset), indicated no reliable differences as a function of either gender or early hormone treatment when the mice were tested under saline (all Fs $<1.0$ ). However, when tested under amphetamine, male mice showed a greater increase in activity compared with saline controls $[\mathrm{F}(1,80)=33.37$, $\mathrm{p}<.0005]$ than did female mice $[\mathrm{F}(1,80)=5.39$,

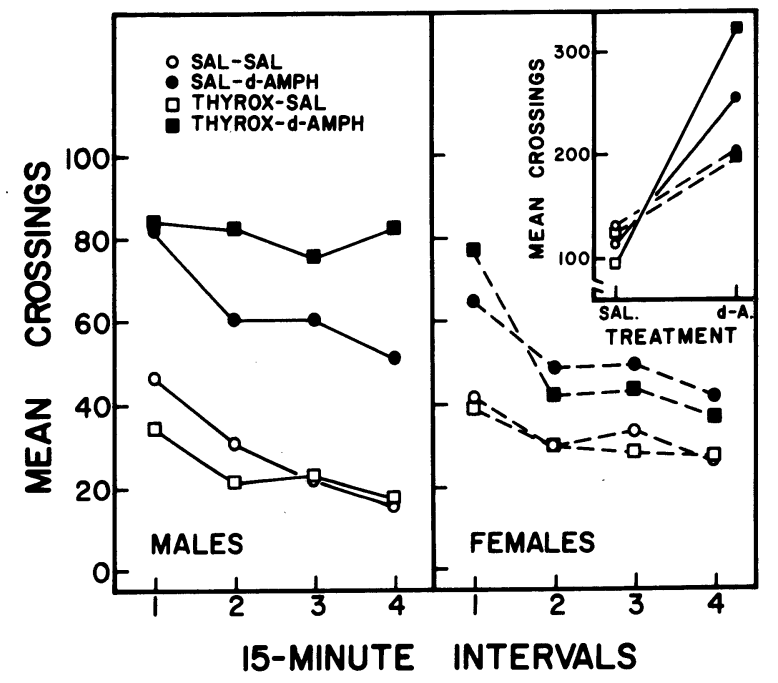

Figure 1. Mean numbers of cage crossings as a function of hormone treatment, drug, sex, and 15-min intervals. $\mathrm{p}<.025]$. Furthermore, male mice that had received early thyroxine treatment displayed higher activity than comparably treated females when tested under amphetamine $[F(1,80)=7.64, p<.01]$, but there was little difference between sexes of early-thyroxine mice when tested under saline $(F<1.0)$. Finally, no differences were found between sexes that had received early saline treatment in their responses to either saline or amphetamine $(\mathrm{Fs}<1.0)$.

The activity differences between sexes as a function of early hormone treatment and test drug are further elucidated when changes in activity across 15 -min intervals are examined in Figure 1. Within sexes, all male groups showed reliable decreases in activity from the first to the last interval [all Fs $(1,240)>4.15$, ps $<.05$ ], with the exception of the thyroxine/amphetamine group, which evidenced little change $[F(1,240)=.03]$. The female groups tested under amphetamine displayed reliable decreases $\left[F_{S}(1,240)=7.26\right.$, ps $\left.<.01\right]$, and those tested under saline showed smaller decreases $[\mathrm{Fs}(1,240)<3.02$, ps $>.05]$. Of all groups tested under amphetamine, only the males exposed to early thyroxine exhibited little change over intervals; all other groups displayed comparable decrements.

\section{DISCUSSION}

The present findings indicate that neonatal hyperthyroidism may produce long-lasting effects on the functioning of $\mathrm{CA}$ systems, at least for the male mouse. The magnitude and temporal pattern of amphetamine-induced potentiation of locomotor activity was altered in the male mouse approximately 100 days after perinatal thyroxine treatment. The effects of neonatal hyperthyroidism appear similar, although not identical, to those of hyperthyroidism induced in the adult. Adult hyperthyroid mice show increased activity following amphetamine injections, but the temporal pattern of locomotor response remains unaltered (Askew, 1962; Coville \& Telford, 1970).

Despite the similarity between the effects reported here and those of adult hyperthyroidism, it appears unlikely that the long-term effects of neonatal hyperthyroidism are due to thyroid excess at the time of testing. While it has been suggested that the presence of excess thyroid hormone during early development may interfere with the normal maturation of the hypothalamopituitary-thyroid axis (Eayrs, 1964), experiments designed to test such a hypothesis have failed to provide adequate evidence for chronic hyper- or hypothyroid conditions in the adult following neonatal thyroid excess (Davenport \& Gonzalez, 1973; Eayrs, 1971). Therefore, it appears likely that the present results were a consequence of the prior altered maturation of the CA system induced by thyroxine-accelerated development. The failure to obtain effects of neonatal thyroxine in the adult female suggests, perhaps, that the female is more resistant to the long-term effects of neonatal hyperthyroidism, as numerous studies of the effects of neonatal thyroxine have reported comparable results for both sexes when examined at early ages (Murphy \& Nagy, 1976; Rastogi \& Singhal, 1976).

\section{REFERENCES}

Askew, B. M. Hyperpyrexia as a contributing factor in the toxicity of amphetamine to aggregated mice. British Journal of Pharmacology, 1962, 19, 245-257.

Coville, P. F., \& Telford, J. M. The effect of thyroid hormones on the action of some centrally acting drugs. British Journal of Pharmacology, 1970, 40, 747-758. 
Davenport, J. W., \& Gonzalez, L. M. Neonatal thyroxine stimulation in rats: Accelerated behavioral maturation and subsequent learning deficit. Journal of Comparative and Physiological Psychology, 1973, 85, 397-408.

EAYRs, J. T. Effects of neonatal hyperthyroidism on maturation and learning in the rat. Animal Behaviour, 1964, 12, 195-199.

EAYRs, J. T. Thyroid and developing brain: Anatomical and behavioral effects. In M. Hamburgh \& E. J. W. Barrington (Eds.), Hormones in development. New York: AppletonCentury-Crofts, 1971.

Emlen, W., Segal, D. S., \& Mandell, A. J. Thyroid state: Effects on pre- and postsynaptic central noradrenergic mechanisms. Science, 1972, 175, 79-82.

Engstrom, G., Svensson, T. H., \& Waldeck, B. Thyroxine and brain catecholamines: Increased transmitter synthesis and increased receptor sensitivity. Brain Research, 1974, 77, 471-483.

GEeL, S. E., \& TImiras, P. S. Influence of hypothyroidism and of thyroxine on the acetylcholinesterase and cholinesterase activities of the developing central nervous system of the rat. Endocrinology, 1967, 80, 1069-1074.

Halpern, B. N., Drudi-Baracco, C., \& Bessirard, D. Exaltation of toxicity of sympathomimetic amines by thyroxine. Nature, 1964, 204, 387-388.

Ito, J. M., Valcana, T., \& Timiras, P. S. Effect of hypoand hyperthroidism on regional monoamine metabolism in the adult rat brain. Neuroendocrinology, 1977, 24, 55-64.
Murphy, J. M., \& NAGY, Z. M. Neonatal thyroxine stimulation accelerates the maturation of both locomotor and memory processes in mice. Journal of Comparative and Physiological Psychology, 1976, 90, 1082-1091.

Rastogi, R. B., \& Singhal, R. L. Neonatal hyperthyroidism: Alterations in behavioral activity and the metabolism of brain norepinephrine and dopamine. Life Sciences, 1976, 18, 351-358.

Salas, M., Diaz, S., \& Cintra, L. Electrocortical effects of early postnatal thyroxine administration in the rat. Physiology \& Behavior, 1976, 17, 239-244.

Schapiro, S. Some physiological, biochemical, and behavioral consequences of neonatal hormone administration: Cortisol and thyroxine. General and Comparative Endocrinology, 1968, 10 214-228.

SchapIRo, S. Hormonal and environmental influences on rat brain development and behavior. In M. B. Sterman, D. J. McGinty, \& A. M. Adinolfi (Eds.), Brain development and behavior. New York: Academic Press, 1971.

Schapiro, S., Vukovich, K., \& Globus, A. Effects of neonatal thyroxine and hydrocortisone administration on the development of dendritic spines in the visual cortex of rats. Experimental Neurology, 1973, 40, 286-296.

WINER, B. J. Statistical principles in experimental design (2nd ed.). New York: McGraw-Hill, 1971

(Received for publication October 16, 1981.) 